\section{Differential Tolerance of Fresh Market Sweet Corn Cultivars to the Herbicides Nicosulfuron and Primisulfuron}

\author{
Timothy L. Grey ${ }^{1}$, David C. Bridges ${ }^{2}$, Paul Raymer ${ }^{3}$, Don Day ${ }^{4}$, and \\ D. Scott NeSmith ${ }^{5}$ \\ Department of Crop and Soil Science, College of Agriculture and \\ Environmental Sciences, The University of Georgia, Georgia Station, 1109 \\ Experiment Street, Griffin, GA 30223-1797
}

Additional index words. Zea mays, vegetables, injury, weed control, yield, sulfonylurea

\begin{abstract}
Field studies were conducted to determine the tolerance of 11 sweet corn (Zea mays L.) cultivars to the herbicides nicosulfuron and primisulfuron. The $s u$ cultivar 'Merit' was intolerant of nicosulfuron and primisulfuron, as indicated by significant differences from the untreated check for all measured variables. Most other $s u$ cultivars exhibited stunting, but injury was $\leq 19 \%(0 \%=$ no injury; $100 \%=$ dead $)$ with nicosulfuron and primisulfuron in 1992. The se cultivars Alpine and Harris Moran Silverado exhibited variable stunting to nicosulfuron (25\% and $23 \%$ injury, respectively) and primisulfuron $(43 \%$ and $50 \%$, respectively) in 1992. The $s h 2$ cultivar Supersweet Jubilee was injured less by nicosulfuron (16\%) than by primisulfuron (33\%) in 1992. All cultivars except Merit recovered from early-season herbicide injury in 1992 and 1993. Significant differences among the $s e, s u$, and $s h 2$ cultivars were recorded for the remaining variables (stalk height, marketable ear number and yield, ear length and diameter), but no patterns with respect to a specific sugary genetic background developed in 1992 or 1993. Nicosulfuron and primisulfuron were safely applied to the cultivars Alpine, Harris Moran Silverado, Royal Gold, Seneca Chief, Calumet, Jubilee, and Supersweet Jubilee without reductions in fresh ear yield. Chemical names used:

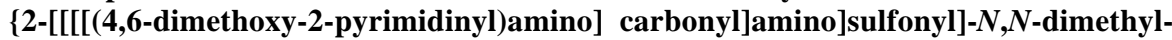
3-pyridinecarboxamide\} (nicosulfuron); \{methyl 2[[[[[4,6-bis(difluoromethoxy)-2pyrimidinyl]amino]carbonyl]amino]sulfonyl]benzonate\} (primisulfuron).
\end{abstract}

In $1999,28 \%$ of the United States fresh sweet corn market was produced in the southeastern states of Alabama ( 850 ha), Florida (15,270 ha), Georgia (8480 ha), and North Carolina (2820 ha) (National Agricultural Statistics Service, 2000). This regional production accounted for $>36 \%$ of the national $\$ 458$ million market (National Agricultural Statistics Service, 2000). Most southeastern sweet corn is shipped to retailers along the eastern half of the United States (D.M.

Received for publication 18 Oct. 1999. Accepted for publication 18 Feb. 2000. We gratefully acknowledge the contributions of the following technical staff to the conduct and publication of this research: D. Berry, W. Slaughter, R. Rivers, and E. Moncrief. Statistical services were provided by J. Davis, Experimental Statistics, Univ. of Georgia-Griffin Campus. This research was conducted with State and Hatch funds allocated to the author's research projects and by gifts and grants from various industry sources. The cost of publishing this paper was defrayed in part by the payment of page charges. Under postal regulations, this paper therefore must be marked advertisement solely to indicate this fact. ${ }^{1}$ Assistant Research Scientist, Dept. of Crop and Soil Sciences. E-mail address: tgrey@gaes. griffin.peachnet.edu

${ }^{2}$ Professor, Dept. of Crop and Soil Sciences.

${ }^{3}$ Associate Professor, Dept. of Crop and Soil Sciences.

${ }^{4}$ Senior Agricultural Specialist, Dept. of Crop and Soil Sciences.

${ }^{5}$ Professor, Horticulture Research Center.
Granberry, personal communication). This early-season market is important for producers, retailers, and consumers.

Many of the sweet corn cultivars grown in the southeast and elsewhere have been specifically selected for increased sugar content because of their popularity with consumers (Fritz et al. 1991). However, selective breeding for increased sugar content has reduced seed vigor (Robinson et al., 1996). Lower vigor reduces stand and crop establishment, thus canopy development is slower, leading to increased weed competition (Robinson et al., 1994). cides nicosulfuron and primisulfuron is limited by cultivar differences in tolerance, and research into specific cultivar response on a regional basis has been extensive (Burton et al., 1994; E.I. duPont, 1999a; Monks et al., 1992; Morton et al., 1993; Morton and Harvey 1992; O'Sullivan and Bouw, 1998; Robinson et al., 1994, 1996; Stall et al., 1992; Williams and Harvey, 1996). However, many cultivars have yet to be evaluated.

Herbicides used for control of dicots and annual grasses in fresh sweet corn fields are production. These include $S$-ethyl dipropyl carbamothioate (EPTC) which must be preplant incorporated (PPI), as well as several preemergence (PRE) herbicides, such as pendimethalin [N-(1-ethylpropyl)-3,4-dim-
The use of the sulfonylurea corn herbisimilar to those commonly used in field corn ethyl-2,6-dinitrobenzenamine], alachlor [2chloro-N-(diethylphenyl)- $N$-(methoxymethyl)acetimide], alachlor + atrazine [6chloro- $N$-ethyl- $N^{\prime}$-(1-methylethyl)-1,3,5-triazine-2,4-diamine], and cyanazine $\{2-[[4-$ chloro-6-(ethylamino)-1,3,5-triazin-2yl]amino]-2-methylpropanenitrile . Cyanazine will be removed from the market in Dec. 2002 (E.I. duPont, 1999b). These herbicides commonly control many weed species and loss of other corn herbicides from the market (i.e., atrazine) would result in limited herbicide options for producers of major and minor crops (Abelson, 1997). Failure to control both dicot and grass weeds complicates fresh sweet corn harvest and reduces yield.

Postemergence (POST) herbicide options for dicot weed control are limited to bentazon [3-(1-methylethyl)-(1H)-2,1,3-benzothiadiazin-4-(3H)-one 2,2-dioxide] and 2,4D (2,4-dichlorophenoxy acetic acid], which can only be applied to corn $\leq 20 \mathrm{~cm}$ tall. Bentazon and 2,4-D have little to no residual activity. Ametryn [N-ethyl- $N^{\prime}-(1-$ methylethyl)-6-(methylthio)-1,3,5-triazine2,4-diamine] must be postdirected (PD) in fresh sweet corn. Currently, no herbicides are registered for POST grass control in fresh sweet corn.

Nicosulfuron and primisulfuron were first marketed for control of most annual and some perennial grasses, as well as certain broadleaf weeds, in field corn in 1991 and 1990, respectively (Ahrens, 1994). Currently, nicosulfuron has a supplemental label for use in the United States in Illinois, Iowa, Minnesota, New Jersey, New York, and Wisconsin on contract processing sweet corn only (E.I. duPont, 1999a). However, restrictions are imposed because of the susceptibility of some cultivars to injury from nicosulfuron (Morton and Harvey, 1992; O'Sullivan and Bouw, 1998). The variable tolerance among fresh sweet corn cultivars to the sulfonylurea herbicides has been noted (Monks et al., 1992; Robinson et al., 1994; Stall and Bewick, 1992) and attributed to a specific cultivar's ability to metabolize the parent chemical in the herbicide (Burton et al. 1994). Herbicide safeners will enhance the level of metabolism in tolerant cultivars, but do not reduce injury in nontolerant ones (Burton et al. 1994). Herbicide-insecticide interaction can also increase sensitivity of certain cultivars of field and sweet corn to sulfonlyurea herbicides (Morton, et al., 1991; 1993; Robinson et al. 1996; Williams and Harvey, 1996).

The recessive sugary (su1) allele is common in many sweet corn cultivars. Some of the $s u$ cultivars (e.g., Silver Queen) are tolerant (Stall and Bewick, 1992) to sulfonylurea herbicides, while other cultivars (e.g., Merit) are susceptible (Robinson et al. 1994). Through breeding, the independent, recessive, modifer mutant gene sugar enhanced (sel) can be bred into sul lines, but to obtain the full effects of the high sugary trait in F1 hybirds, both sul parents should be homozygous for the gene (Ferguson et al., 1978). Heterozygous sel cultivars are phenotypically $s u l$ and should respond to environmen- 
tal conditions as do sul cultivars. Stall and Bewick (1992) found no correlation between sensitivity to nicosulfuron and the sh2 or se 1 endosperms of a specific cultivar. However, some cultivars that were intolerant to nicosulfuron contained the sh2 and sel gene. Thus, screening of cultivars is essential for potential future registration of the herbicide for use in fresh sweet corn production.

Currently PPI, PRE, and POST herbicide options are available for weed control in fresh sweet corn production. However, some compounds (e.g., cyanazine) may not be reregistered, and POST grass control options are limited. Registration of nicosulfuron or primisulfuron, currently registered for weed control in field and processing sweet corn, for fresh sweet corn production would provide producers alternative herbicide options. Current registrations for processing sweet corn carry cultivar restrictions. If registration were granted for use of these herbicides, then information about specific cultivars would be required.

The objectives of this investigation were to determine the responses of several fresh sweet corn cultivars that have not undergone previous screening to nicosulfuron and primisulfuron, including: 1) tolerance; 2) ear number; 3) ear diameter; 4) plant height; 5) fodder yield; and 6) total fresh ear yield.

\section{Materials and Methods}

Studies were conducted at the Georgia Experiment Station near Griffin, in 1992, on a Pacolet coarse sandy loam and in 1993 on a Cecil sandy clay loam; both soils were fine, kaolinitic, thermic Typic Kanhapludults. Each year, the treatment area received pendimethalin at $0.8 \mathrm{~kg} \cdot \mathrm{ha}^{-1}$ a.i. PRE for dicot and annual grass control. Commercial sweet corn cultivars commonly grown in the southeastern United States at the time these studies were initiated were selected, based on consultation with extension and seed company representatives. Cultivars included 'Alpine' and 'Harris Moran Silverado' (both heterozygous se1), 'Calumet', 'Deltapine Sweet G-90', 'Iochief', 'Jubilee', 'Merit', 'Royal Gold', 'Seneca Chief', and 'Silver Queen' (sul), and 'Supersweet Jubilee' (sh2) (Table 1).

Table 1. Sweet corn cultivars evaluated for tolerance to nicosulfuron and primisulfuron in Georgia, 1992 and 1993.

\begin{tabular}{lcc}
\hline Cultivar & $\begin{array}{c}\text { Endosperm } \\
\text { type }^{2}\end{array}$ & $\begin{array}{c}\text { Kernel } \\
\text { color }\end{array}$ \\
\hline Alpine & sel & White \\
Harris Moran Silverado & $s e 1$ & White \\
Royal Gold & $s u 1$ & Yellow \\
Seneca Chief & $s u 1$ & Yellow \\
Calumet & $s u 1$ & Yellow \\
Deltapine Sweet G-90 & $s u 1$ & Yellow \\
Iochief & $s u 1$ & Yellow \\
Jubilee & $s u 1$ & Yellow \\
Merit & $s u 1$ & Yellow \\
Silver Queen & $s u 1$ & White \\
Supersweet Jubilee & $s h 2$ & Yellow \\
\hline${ }^{2}$ Abbreviations: se1 = sugary enhancer; sul $=$ sug- \\
ary; sh2 = shrunken-2.
\end{tabular}

HortScience, Vol. 35(6), October 2000
Plants were established each year by $50 \%$ overseeding ( $2.5 \mathrm{~cm}$ soil depth) with a plot planter equipped with seeding cones. After emergence, plots were thinned by hand to a final stand of 49,400 plants per ha. Planting dates were 4 Apr. 1992 and 21 Apr. 1993, following conventional tillage by moldboard plowing and smoothing using a rotary tiller. The experimental design was a split-plot with four replications (blocks). Each plot consisted of six rows $(0.8 \mathrm{~m}$ wide $\times 5.5 \mathrm{~m}$ long $)$ of a single cultivar. Two rows were used per treatment (i.e., nicosulfuron, primisulfuron, and untreated). Fertilizer was applied based on soil test recommendations for sweet corn production and insecticides were applied POST as needed to control insects.

Nicosulfuron (75\% a.i.) and primisulfuron (75\% a.i.) applied at 15 and $18 \mathrm{~g} \cdot \mathrm{ha}^{-1}$, respectively (all concentrations expressed as a.i.). All treatments were applied with a tractormounted boom sprayer using compressed air calibrated to deliver $187 \mathrm{~L} \cdot \mathrm{ha}^{-1}$ at $210 \mathrm{kPa}$. The POST treatments were applied on 1 May 1992 and 1 June 1993 to plants that were 15 and $40 \mathrm{~cm}$ tall, respectively. All plots were maintained weed-free by hand hoeing.

Total leaf necrosis and injury to the whorl, were visually estimated 8 weeks after POST treatment in 1992 using a scale of $0 \%$ (no injury) to $100 \%$ (dead). Each year, one row from each treatment was harvested at optimum roasting ear stage (R3) to determine marketable ear number and weight. Average stalk height for each year was determined for each plot on 10 consecutive stalks by measuring from the ground to the base of the tassel. In 1992 fodder fresh weight/ha (stalks less ears) was determined by harvesting one row in each subplot using a commercial silage chopper. Ear length and diameter were measured on 10 consecutive stalks in 1993.

Injury, plant height, marketable ear number, weight, length and diameter, and fodder fresh weight data were subjected to analysis of variance (ANOVA) and tested for year $x$ treatment interactions. Treatment means were separated with appropriate Fisher's protected least significant difference test (LSD) at $P \leq$ 0.05 , and orthogonal contrasts were made between $s e 1$ vs. sul, sel vs. sh2, and sul vs. sh 2 cultivars.

\section{Results and Discussion}

Treatment $\times$ year interactions were revealed by ANOVA of the data. These factors prevented pooling data for plant height and for marketable ear number, and weight across years. Therefore, all data are presented for each year. 'Merit' was intolerant of nicosulfuron and primisulfuron and thus was killed upon herbicide application, resulting in all variables (injury, fodder weight, height, ear length and diameter, yield in ear number/ha and $\mathrm{kg} \cdot \mathrm{ha}^{-1}$ ) being significantly different from the untreated check (data not shown). Orthogonal contrasts were used to test differences among treatments within the sel, sul, and $s h 2$ cultivars. Treatment means for each endosperm type were combined and contrasted, excluding 'Merit'.

Injury. Injury varied by cultivar (Table 2). Orthogonal contrasts indicated that se 1 cultivars exhibited greater injury than the sul cultivars. 'Merit' was intolerant of both nicosulfuron and primisulfuron (99\% injury), while 'Silver Queen' was nonsignificantly injured, as previously reported (Monks et al., 1992; Stall and Bewick, 1992). The intolerance of 'Merit' has been attributed to the lack of a gene that codes for oxidase enzymes responsible for metabolism of the sulfonlyurea herbicides (Burton et al., 1994). None of the other cultivars included in this study were intolerant to either herbicide.

'Calumet', 'Deltapine Sweet G-90', 'Jubilee', 'Seneca Chief', and 'Royal Gold'

Table 2. Injury means and orthogonal contrasts for sweet corn cultivars evaluated for tolerance to nicosulfuron and primisulfuron in Georgia, 1992.

\begin{tabular}{|c|c|c|c|c|}
\hline \multirow[b]{2}{*}{ Cultivar } & \multicolumn{4}{|c|}{ Injury $(\%)$} \\
\hline & Nicosulfuron $^{2}$ & Primisulfuron $^{y}$ & Check & $\overline{\mathrm{LSD}_{0.05}}$ \\
\hline Alpine & 25 & 43 & 0 & 8 \\
\hline Harris Moran Silverado & 23 & 50 & 0 & 13 \\
\hline Royal Gold & 1 & 1 & 0 & NS \\
\hline Seneca Chief & 11 & 16 & 0 & 10 \\
\hline Calumet & 6 & 9 & 0 & NS \\
\hline Deltapine Sweet G-90 & 6 & 19 & 0 & 8 \\
\hline Iochief & 13 & 19 & 0 & 11 \\
\hline Jubilee & 14 & 39 & 0 & 15 \\
\hline Merit & 99 & 99 & 0 & 1 \\
\hline Silver Queen & 5 & 6 & 0 & NS \\
\hline Supersweet Jubilee & 16 & 33 & 0 & 15 \\
\hline \multicolumn{5}{|c|}{ Orthogonal contrast $^{\mathrm{x}}$} \\
\hline sel vs. sul & $\operatorname{sel}>\operatorname{su} 1^{* * * *}$ & sel $>$ su $1^{* *}$ & NS & \\
\hline se 1 vs. sh2 & NS & $\operatorname{se} 1>\operatorname{sh} 2^{*}$ & NS & \\
\hline su 1 vs. $\operatorname{sh} 2$ & NS & $\operatorname{sh} 2>\operatorname{sul} 1^{* *}$ & NS & \\
\hline
\end{tabular}

${ }^{\mathrm{z}}$ Applied at $15 \mathrm{~g} \cdot \mathrm{ha}^{-1}$ a.i.

${ }^{\mathrm{y}}$ Applied at $18 \mathrm{~g} \cdot \mathrm{ha}^{-1}$ a.i.

'Orthogonal contrast for se 1 cultivars: Alpine and Harris Moran Silverado. su cultivars: 'Calumet', 'Deltapine Sweet G-90', 'Iochief', 'Jubilee', 'Silver Queen', 'Royal Gold', and 'Seneca Chief' ('Merit' was not included). sh2 cultivar: 'Supersweet Jubilee'.

ns, ${ }^{*}, * * * * *$ Nonsignificant or significant at $P \leq 0.05,0.01$, and 0.001 levels, respectively, for Fisher's protected LSD test. 
were not significantly injured by nicosulfuron, but 'Alpine' and 'Silverado' were. O'Sullivan and Bouw (1998) reported cultivar differences in tolerance to nicosulfuron/rimsulfuron mixtures for sel cultivars of sweet corn and for the $s h 2$ cultivar Supersweet Jubilee, which was significantly injured (16\%) in our study.

Primisulfuron was more injurious than nicosulfuron in all cultivars. The sel cultivars Alpine and Silverado were significantly injured (43\% and 50\%, respectively). 'Royal Gold' had the greatest tolerance (1\% injury) of any of the sul cultivars and 'Calumet' was not significantly injured by primisulfuron, but injury to 'Deltapine Sweet G-90', 'Iochief', 'Jubilee', and 'Supersweet Jubilee' was $19 \%, 19 \%, 39 \%$, and 33\%, respectively. Greater injury from primisulfuron than from nicosulfuron has been previously reported for several sweet corn cultivars (Monks et al., 1992).

Fodder weight and stalk height. Neither herbicide affected fodder weight in 1992 except in 'Merit' (data not presented). Height of 'Royal Gold', 'Deltapine Sweet G-90', 'Silver Queen', and 'Supersweet Jubilee' was not significantly reduced in 1992 or 1993 (Table 3). Orthogonal contrasts indicated that herbicide-treated sul cultivars were significantly taller than se 1 or sh 2 cultivars in 1992 and 1993. In 1992, orthogonal contrasts indicated no differences among cultivars in nontreated plants, but in 1993, all three contrasts were significant. Morton and Harvey (1992) noted differences in injury to 'Jubilee' with nicosulfuron in Wisconsin.

Height of 'Alpine', 'Harris Moran Siverado', 'Iocheif', and 'Jubilee' was reduced by nicosulfuron in 1992, but reductions were significant only in 'Alpine' and 'Calumet' in 1993. This variation could be attributed to the timing of herbicide application (at $15 \mathrm{~cm}$ in 1992 and $40 \mathrm{~cm}$ in 1993). Morton and Harvey (1992) noted vigor, but not plant height, of 'Jubilee' and other hybrids declined with increasing nicosulfuron rate. Robinson et al. (1994) observed reduced tolerance of 'Zenith' as nicosulfuron was applied at increasing heights up the stalk. O'Sullivan and Bouw (1998) reduced the height of processing sweet corn cultivars by increasing the application rate of a nicosulfuron/rimsulfuron mixture from 25 to $50 \mathrm{~g} \cdot \mathrm{ha}^{-1}$.

Primisulfuron reduced the height of 'Alpine', 'Harris Moran Silverado', 'Seneca Chief', 'Iochief', and 'Jubilee' in 1992; however, 'Iochief' was the only cultivar with a significant height reduction in 1993. Again, this trend could be attributed to exposure when plants were taller in 1993 than in 1992.

Ear length and diameter. Ear length and diameter were affected in 'Alpine', 'Harris Moran Silverado', 'Royal Gold', 'Seneca Chief', 'Calumet', 'Deltapine Sweet G-90', and 'Jubilee'. Ear length of 'Iochief' and 'Supersweet Jubilee' was significantly reduced by primisulfuron $(2 \mathrm{~cm} /$ ear reduction) and nicosulfuron $(4 \mathrm{~cm} /$ ear reduction) (data

Table 3. Stalk height $(\mathrm{cm})$ means and orthogonal contrasts for sweet corn cultivars evaluated for tolerance to nicosulfuron and primisulfuron in Georgia.

\begin{tabular}{|c|c|c|c|c|c|c|c|c|}
\hline \multirow{3}{*}{$\frac{\text { Cultivar }}{\text { Alpine }}$} & \multicolumn{4}{|c|}{1992} & \multicolumn{4}{|c|}{1993} \\
\hline & Nicosulfuron $^{2}$ & Primisulfuron $^{\mathrm{y}}$ & Check & $\mathrm{LSD}_{0.05}$ & Nicosulfuron & Primisulfuron & Check & $\mathrm{LSD}_{0.05}$ \\
\hline & 136 & 131 & 154 & 16 & 91 & 104 & 105 & 10 \\
\hline Harris Moran Silverado & 130 & 120 & 146 & 9 & 100 & 98 & 110 & NS \\
\hline Royal Gold & 171 & 170 & 175 & NS & 154 & 153 & 153 & NS \\
\hline Seneca Chief & 144 & 130 & 148 & 7 & 104 & 105 & 108 & NS \\
\hline Calumet & 155 & 155 & 161 & NS & 146 & 164 & 162 & 12 \\
\hline Deltapine Sweet G-90 & 164 & 153 & 160 & NS & 140 & 134 & 142 & NS \\
\hline Jubilee & 154 & 134 & 164 & 8 & 126 & 115 & 128 & NS \\
\hline Silver Queen & 158 & 149 & 158 & NS & 144 & 144 & 153 & NS \\
\hline Supersweet Jubilee & 138 & 130 & 145 & NS & 108 & 109 & 121 & NS \\
\hline \multicolumn{9}{|c|}{ Orthogonal contrast $^{\mathrm{x}}$} \\
\hline sel vs. sul & $\operatorname{sul}>\operatorname{sel}^{* *}$ & sul $1>\operatorname{se} 1^{* * * *}$ & NS & & $\operatorname{sul} 1>\operatorname{se} 1^{* * * *}$ & sul $>\operatorname{se} 1^{* * * *}$ & $\operatorname{sul}>\operatorname{se} 1^{* * * *}$ & \\
\hline se 1 vs. $\operatorname{sh} 2$ & NS & NS & NS & & NS & NS & $\operatorname{se} 1>\operatorname{sh} 2^{*}$ & \\
\hline su 1 vs. sh 2 & $\operatorname{sul} 1>\operatorname{sh} 2^{* * *}$ & $\operatorname{su} 1>\operatorname{sh} 2^{* *}$ & NS & & $\operatorname{su} 1>\operatorname{sh} 2^{* * *}$ & $\operatorname{sul} 1>\operatorname{sh} 2^{* * *}$ & $\operatorname{su} 1>\operatorname{sh} 2^{* * *}$ & \\
\hline
\end{tabular}

${ }^{\mathrm{z}}$ Applied at $15 \mathrm{~g} \cdot \mathrm{ha}^{-1} \mathrm{a} . \mathrm{i}$.

${ }^{y}$ Applied at $18 \mathrm{~g} \cdot \mathrm{ha}^{-1}$ a.i.

'Orthogonal contrast for se1 cultivars: 'Alpine' and 'Harris Moran Silverado'. su1 cultivars: 'Calumet', 'Deltapine Sweet G-90', 'Iochief', 'Jubilee', 'Silver Queen', 'Royal Gold', and 'Seneca Chief' ('Merit' was not included). sh2 cultivar: 'Supersweet Jubilee'.

Ns, *,**,*** Nonsignificant or significant at $P \leq 0.05,0.01$, and 0.001 levels, respectively, for Fisher's protected LSD test.

Table 4. Number of marketable ears/ha (in 1000's) and orthogonal contrasts for sweet corn cultivars evaluated for tolerance to nicosulfuron and primisulfuron in Georgia.

\begin{tabular}{|c|c|c|c|c|c|c|c|c|}
\hline \multirow{3}{*}{$\frac{\text { Cultivar }}{\text { Alpine }}$} & \multicolumn{4}{|c|}{1992} & \multicolumn{4}{|c|}{1993} \\
\hline & Nicosulfuron $^{2}$ & Primisulfuron $^{\mathrm{y}}$ & Check & $\overline{\mathrm{LSD}_{0.05}}$ & Nicosulfuron & Primisulfuron & Check & $\mathrm{LSD}_{0.05}$ \\
\hline & 33 & 24 & 29 & NS & 18 & 23 & 21 & NS \\
\hline Harris Moran Silverado & 26 & 23 & 30 & NS & 25 & 21 & 21 & 2 \\
\hline Royal Gold & 24 & 21 & 23 & NS & 21 & 24 & 22 & NS \\
\hline Seneca Chief & 12 & 24 & 21 & NS & 26 & 17 & 20 & NS \\
\hline Calumet & 14 & 14 & 16 & NS & 21 & 14 & 16 & 4 \\
\hline Deltapine Sweet G-9017 & 12 & 18 & NS & 17 & 21 & 19 & NS & \\
\hline Jubilee & 25 & 24 & 29 & NS & 21 & 20 & 18 & NS \\
\hline Silver Queen & 18 & 13 & 18 & NS & 14 & 19 & 17 & NS \\
\hline Supersweet Jubilee & 19 & 12 & 21 & 6 & 19 & 18 & 22 & NS \\
\hline \multicolumn{9}{|c|}{ Orthogonal contrast $^{\mathrm{x}}$} \\
\hline sel vs. sul & $\operatorname{sel}>\operatorname{su} 1^{* * * *}$ & $s e 1>s u 1^{*}$ & se $1>s u 1^{*}$ & & NS & NS & NS & \\
\hline se 1 vs. sh2 & $\operatorname{se} 1>\operatorname{sh} 2^{* * * *}$ & $\operatorname{se} 1>\operatorname{sh} 2^{* *}$ & $\operatorname{se} 1>\operatorname{sh} 2^{*}$ & & NS & NS & NS & \\
\hline su 1 vs. sh 2 & NS & NS & NS & & NS & NS & NS & \\
\hline
\end{tabular}

${ }^{\mathrm{z}}$ Applied at $15 \mathrm{~g} \cdot \mathrm{ha}^{-1}$ a.i.

${ }^{\mathrm{y}}$ Applied at $18 \mathrm{~g} \cdot \mathrm{ha}^{-1}$ a.i.

‘Orthogonal contrast for se 1 cultivars: 'Alpine' and 'Harris Moran Silverado'. sul cultivars: 'Calumet', 'Deltapine Sweet G-90', 'Iochief', 'Jubilee', 'Silver Queen', 'Royal Gold', and 'Seneca Chief' ('Merit' was not included). sh2 cultivar: 'Supersweet Jubilee'.

ns, ***, ****Nonsignificant or significant at $P \leq 0.05,0.01$, and 0.001 levels, respectively, for Fisher's protected LSD test. 
Table 5. Yield of marketable ears $\left(\mathrm{kg} \cdot \mathrm{ha}^{-1}\right)$ for sweet corn cultivars evaluated for tolerance to nicosulfuron and primisulfuron in Georgia.

\begin{tabular}{|c|c|c|c|c|c|c|c|c|}
\hline \multirow[b]{2}{*}{ Cultivar } & \multicolumn{4}{|c|}{1992} & \multicolumn{4}{|c|}{1993} \\
\hline & Nicosulfuron $^{z}$ & Primisulfuron $^{\mathrm{y}}$ & Check & $\overline{\mathrm{LSD}_{0.05}}$ & Nicosulfuron & Primisulfuron & Check & $\overline{\mathrm{LSD}_{0.05}}$ \\
\hline Alpine & 6070 & 5340 & 6750 & NS & 3100 & 3770 & 3560 & NS \\
\hline Harris Moran Silverado & 5300 & 4850 & 7090 & NS & 4630 & 3780 & 4780 & NS \\
\hline Royal Gold & 5690 & 4830 & 5530 & NS & 4190 & 4840 & 4650 & NS \\
\hline Seneca Chief & 2470 & 4460 & 4320 & NS & 3970 & 3070 & 3920 & NS \\
\hline Calumet & 3120 & 3360 & 3770 & NS & 3790 & 3240 & 3560 & NS \\
\hline Deltapine Sweet G-90 & 3820 & 2810 & 4470 & 1080 & 3560 & 4720 & 4350 & NS \\
\hline Jubilee & 5640 & 5500 & 6970 & NS & 3920 & 4190 & 3990 & NS \\
\hline Silver Queen & 3660 & 2940 & 3940 & NS & 2890 & 4170 & 4170 & 950 \\
\hline Supersweet Jubilee & 4500 & 2810 & 5230 & 1910 & 3130 & 2870 & 4580 & NS \\
\hline \multicolumn{9}{|c|}{ Orthogonal contrast ${ }^{\mathrm{x}}$} \\
\hline sel vs. sul & sel $1>$ su $1^{*}$ & sel $>$ sul $1^{*}$ & sel $>$ sul $1^{*}$ & & NS & NS & NS & \\
\hline se 1 vs. sh 2 & NS & $\operatorname{se} 1>\operatorname{sh} 2^{* * *}$ & NS & & NS & NS & NS & \\
\hline sul vs. sh 2 & NS & NS & NS & & NS & NS & NS & \\
\hline
\end{tabular}

${ }^{\mathrm{z}}$ Applied at $15 \mathrm{~g} \cdot \mathrm{ha} \mathrm{a}^{-1}$ a.i.

${ }^{\mathrm{y}}$ Applied at $18 \mathrm{~g} \cdot \mathrm{ha}^{-1}$ a.i.

'Orthogonal contrast for sel cultivars: 'Alpine' and 'Harris Moran Silverado'. sul cultivars: 'Calumet', 'Deltapine Sweet G-90', 'Iochief', 'Jubilee',

'Silver Queen', 'Royal Gold', and 'Seneca Chief' ('Merit' was not included). sh2 cultivar: 'Supersweet Jubilee'.

Ns, ${ }^{*},{ }^{*}, * * *$ Nonsignificant or significant at $P \leq 0.05,0.01$, and 0.001 levels, respectively for Fisher's protected LSD test.

not presented) and 'Silver Queen' ear diameter was significantly reduced by nicosulfuron (4 $\mathrm{mm} /$ ear reduction), but ear length was unaffected. Overall, there was no consistent effect of either herbicide on ear length or diameter.

Marketable ear number. Orthogonal contrasts in 1992 indicated that marketable ear number was greater in sel cultivars than in $s u 1$ or $s h 2$ cultivars treated with nicosulfuron or primisulfuron, but this was not true in 1993. While there was significant injury to the sel cultivars in 1993, it did not affect marketable ear number.

Marketable ear number was increased for nicosulfuron-treated cultivars Alpine, Royal Gold, and Silver Queen in 1992 and for 'Harris Moran Silverado', 'Calumet', 'Seneca Chief', 'Iochief', and 'Jubilee' in 1993 (Table 4). Yields of all other cultivars were nonsignificantly reduced as compared to the untreated check.

Primisulfuron did not affect marketable ear number in 'Seneca Chief' in 1992 or in 1993 for 'Alpine', 'Royal Gold', 'Deltapine Sweet G-90', or 'Jubilee'. Marketable ear number of 'Supersweet Jubilee' was reduced in 1992, but not in 1993; ear number was not affected in other cultivars.

Yield. Yield $\left(\mathrm{kg} \cdot \mathrm{ha}^{-1}\right)$ generally reflected, but was less variable than marketable ear number/ha (Table 5). Primisulfuron reduced yield of 'Deltapine Sweet G-90' and 'Supersweet Jubilee' in 1992 and that of 'Iochief' in 1993; and nicosulfuron reduced yield of 'Silver Queen' in 1993. Yields of other cultivars did not differ from those of the untreated checks. Monks et al. (1992) also noted that nicosulfuron reduced yield of 'Silver Queen'. Morton and Harvey (1992) reported differential cultivar tolerance to nicosulfuron in a 2-year study and associated it with factors such as soil type, organic matter, moisture, and temperature.

\section{Conclusion}

These data indicate that POST application of nicosulfuron or primisulfuron to fresh sweet corn cultivars caused injury, and reduced fodder weight, stalk height, and ear yield, but response was cultivar-specific. However, marketable qualities, such as ear length and ear diameter, were not adversely affected except in 'Merit' in which plants were killed.

Overall, these data suggest that cultivar response to these herbicides is predictable, given proper screening, and that nicosulfuron and primisulfuron can be used safely on the cultivars examined. However, several new cultivars of sweet corn have been introduced in the southeastern United States and their responses should be evaluated.

\section{Literature Cited}

Abelson, P.H. 1997. Uncertainties about crop protection. Weed Technol. 11:629-632.

Ahrens, W.H. (ed.). 1994. Herbicide handbook. Seventh ed. Weed Sci. Soc.Amer. Champaign, Ill.

Burton, J.D., E.P. Maness, D.W. Monks, and D.K Robinson. 1994. Sulfonylurea selectivity and safener activity in 'Landmark' and 'Merit' sweet corn. Pesticide Biochem. Phys. 48:163-172.

E.I. duPont. 1999a. Accent supplemental labeling. Accent herbicide for weed control in sweet corn for processing in the states of Minnesota, Wisconsin, Illinois, and Iowa. E.I. duPont de Nemours and Co., Agr. Products, Wilmington, Del.

E.I. duPont. 1999b. Bladex 4L label. E.I. du Pont de Nemours and Company, Agr. Products, Wilmington, Del.

Ferguson, J.E., A.M. Rhodes, and D.B. Dickinson. 1978. The genetics of sugary enhancer (se), an independent modifier of sweet corn $(\mathrm{su})$. J. of Hered. 69:377-380.
Fritz, V.A., J.B. Hebel, and A.M. Borowski. 1991. Sweet corn genotypes vs. ethephon in relation to yield components. Agron. J. 83:991-995.

Georgia Agricultural Statistics Service. 1997. Georgia agricultural facts, 1993-1997. Georgia Agr. Stat. Serv., Athens.

Mizelle, W.O. 1999. Georgia vegetable acreage estimates (AGECON 93-027). Coop. Ext. Service. U.S. Dept. of Agr. The Univ. of Georgia College of Agri. and Environ. Sci., Athens, $\mathrm{Ga}$.

Monks, D.W., C.A. Mullins, and K.E. Johnson. 1992. Response of sweet corn to nicosulfuron and primisulfuron. Weed Technol. 6:280-282.

Morton, C.A. and R.G. Harvey. 1992. Sweet corn hybird tolerance to nicosulfuron. Weed Technol. 6:91-96.

Morton, C.A., R.G. Harvey, J.J. Kells, D.A. Landis, W.E. Lueschen, and V.A. Fritz. 1993. In- furrow terbufos reduces field and sweet corn tolerance to nicosulfuron. Weed Tech. 7:934-939.

Morton, C.A., R.G. Harvey, J.J. Kells, W.E. Lueschen, and V.A. Fritz. 1991. Effect of DPX- V9360 and terbufos on field and sweet corn under three environments. Weed Technol 5:130-136.

National Agricultural Statistics Service. 2000. National Agricultural Statistics Service U.S. Dept. of Agr. 1999 Annu. summary. NASS-USDA, Washington, D.C.

O'Sullivan, J. and W.J. Bouw. 1998. Sensitivity of processing sweet corn cultivars to nicolsulfuron/ rimsulfuron. Can. J. Plant Sci. 78:151-154.

Robinson, D.K., D.W. Monks, and J.D. Burton. 1996. Safening influence of LAB 145138 on nicosulfuron, terbufos, and bentazon interactions in sweet corn. Weed Sci. 44:339-344.

Robinson, D.K., D.W. Monks, and J.R. Schultheis. 1994. Effect of nicosulfuron applied postemergence and post-directed on sweet corn tolernece. Weed Technol. 8:630-634.

Stall, M.W. and T.A. Bewick. 1992. Sweet corn cultivars respond differentially to the herbicide nicosulfuron. HortScience 27:131-133.

Williams, B.J. and R.G. Harvey. 1996. Nicosulfuron tolerance in sweet corn as affected by hybrid, rootworm insecticide, and nicosulfuron treatment. Weed Technol. 10:488-494. 